\title{
DETERMINAN DAN STABILITAS EKSPOR CRUDE PALM OIL INDONESIA
}

\author{
Eva Nurul Huda \\ Fakultas Ekonomi dan Bisnis, Universitas Muhammadiyah Yogyakarta \\ evanhuda14@gmail.com \\ Arif Widodo \\ Fakultas Ekonomi dan Bisnis, Universitas Muhammadiyah Yogyakarta \\ rifdoisme@gmail.com
}

\begin{abstract}
We analyze the influence of $C P O$ production, exchange rate, international $C P O$ price and the terms of trade on Indonesian CPO exports in October 2011-December 2015. In doing so, we use the Autoregressive Distributed Lag (ARDL) approach to analyze the monthly time-series data for the periods of 2011:M10-2015:M12. Our findings suggest that both in the short-and long-term, the international CPO price has a significantly negative impact on Indonesia's CPO exports. Meanwhile, the CPO production and exchange rate have negative and significant effects on Indonesia's CPO exports both in short- and long-term. Taken together, all the independent variables have significant effects on Indonesia's CPO export. Finally, based on CUSUM and CUSUMQ test, it shows that the long-term coefficient of the CPO exports model is stable.
\end{abstract}

Keyword: $C P O$ exports, term of trade, autoregressive distributed lag.

\begin{abstract}
ABSTRAK
Tujuan dari studi ini adalah untuk menganalisis seberapa besar pengaruh dari produksi kelapa sawit, nilai tukar rupiah terhadap dollar AS, harga CPO internasional dan Term of Trade terhadap ekspor CPO Indonesia pada periode Oktober 2011 sampai dengan Desember 2015. Penelitian ini menggunakan pendekatan Autoregressive Distributed Lag (ARDL) dengan data sekunder runtut waktu bulanan untuk periode 2011:M10-2015:M12. Hasil dari penelitian ini menunjukkan bahwa harga CPO internasional mempunyai efek negatif dan signifikan, baik dalam jangka pendek maupun jangka panjang terhadap ekspor CPO Indonesia. Variable Term of Trade dalam jangka pendek maupun panjang mempunyai efek positif dan signifikan terhadap ekspor CPO, sedangkan variabel produksi kelapa sawit dan nilai tukar rupiah terhadap dolar Amerika mempunyai pengaruh negatif dan signifikan terhadap ekspor dalam jangka pendek maupun panjang. Lebih lanjut, semua variabel independen secara bersama-sama mempengaruhi ekspor CPO di Indonesia, sehingga hipotesis yang menunjukkan tidak ada hubungan antara variabel independen dan dependen ditolak. Terakhir, berdasarkan pada uji CUSUM dan CUSUMQ dapat disimpulkan bahwa model ekspor CPO stabil dalam jangka panjang.
\end{abstract}

Kata kunci: ekspor CPO, term of trade, autoregressive distributed lag. 


\section{PENDAHULUAN}

Bagi negara berkembang khususnya Indonesia, sumber pembiayaan yang berupa penerimaan devisa yang berasal dan kegiatan ekspor memegang peranan yang sangat penting dalam pembangunan nasional. Salah satu upaya pemerintah untuk mendapatkan devisa dari luar negeri adalah dengan jalan mengekspor hasil-hasil sumber daya alam ke luar negeri. Dari hasil devisa ini dapat digunakan untuk menambah dana pembangunan dalam negeri (Huda 2006).

Salah satu sektor agroindustri Indonesia yang sangat berkembang dan memiliki prospek baik ke depan adalah industri komoditas kelapa sawit. Kelapa sawit yang diolah menjadi minyak kelapa sawit atau Crude Palm Oil (CPO) memegang peran penting dalam perekonomian nasional yaitu sebagai komoditi andalan ekspor non-migas Indonesia penghasil devisa negara di luar minyak dan gas (Agustian 2002). Sejak tahun 2013 hingga 2015, nilai ekspor minyak kelapa sawit olahannya dari sekitar US\$20.660,4 hingga mencapai US\$20.746,9 juta. Dilihat peranannya, pada tahun 2015 peranan ekspor kelapa sawit mencapai 19,45 persen (Lampiran 1). Inilah fakta mengapa pentingnya meneliti lebih dalam perihal ekspor minyak kelapa sawit.

Cerahnya prospek komoditi minyak kelapa sawit dalam perdagangan minyak nabati dunia telah mendorong pemerintah Indonesia untuk memacu pengembangan areal perkebunan kelapa sawit. Selama 25 tahun terakhir ini telah terjadi peningkatan yang sangat signifikan pada luas areal perkebunan kelapa sawit. Hal tersebut terlihat dari data areal perkebunan sawit tahun 1991 yang jumlahnya hanya sekitar 38 ribu hektar dan semakin meluas menjadi lebih dari 11 juta hektar pada tahun 2015 (Dirjen Perkebunan 2016).

Seiring dengan bertambahnya luas perkebunan kelapa sawit, total produksi minyak kelapa sawit Indonesia turut meningkat tajam. Selama 25 tahun terakhir ini telah terjadi peningkatan produksi minyak kelapa sawit sebesar 28,2 juta ha, yaitu dari 2,65 juta ton pada tahun 1991 menjadi 30,94 juta ha pada tahun 2015. Menurut data Dirjen Perkebunan (2016), dengan raihan total produksi yang menyentuh angka lebih dari 30 juta ton per tahunnya, menjadikan Indonesia sebagai negara produsen kelapa sawit terbesar di dunia dengan prosentase 54.51 persen dari total produksi dunia. Jauh melebihi produksi Malaysia yang duduk diperingkat kedua dengan total produksi 33,65 persen dari total seluruh produksi kelapa sawit dunia. Produksi minyak kelapa sawit Indonesia sebagian besar diekspor ke mancanegara dan sisanya dipasarkan di dalam negeri. Total ekspor minyak kelapa sawit 15 tahun terakhir cenderung mengalami peningkatan. Pada tahun 2000 total volume ekspor CPO mencapai 4,68 juta ton, meningkat menjadi 26,4 juta ton pada tahun 2015. Luas areal perkebunan dan total produksi minyak kelapa sawit yang senantiasa bertambah merupakan bukti bahwa komoditas ini memang penting bagi kemajuan ekspor dan cadangan devisa. 
Perkembangan ekspor minyak kelapa sawit Indonesia ternyata dipengaruhi oleh beberapa faktor, misalnya Munadi (2007) meneliti tentang permintaan ekspor minyak kelapa sawit Indonesia ke India menemukan bahwa harga minyak kelapa sawit dunia dan total produksi sangat berpengaruh terhadap ekspor $C P O$. Selain itu, Wulantoro (2009) meneliti tentang kebijakan dan pertumbuhan ekspor minyak kelapa sawit Indonesia ke negara Belanda. Hasil analisis menunjukkan bahwa nilai tukar rupiah terhadap USD tidak signifikan terhadap ekspor minyak kelapa sawit Indonesia ke negara Belanda. Harga ekspor minyak sawit Indonesia, harga pesaing Malaysia dan produksi minyak sawit signifikan terhadap ekspor minyak kelapa sawit Indonesia ke negara Belanda. Abidin (2008) juga menyatakan bahwa faktor utama pendorong kenaikan permintaan minyak kelapa sawit $(C P O)$ adalah harga yang relatif rendah dibandingkan dengan harga kompetitornya seperti minyak kedelai, minyak biji matahari, minyak kacang tanah, minyak kapas dan minyak lobak.

Variabel makroekonomi lain yang memiliki pengaruh terhadap perkembangan ekspor minyak kelapa sawit Indonesia adalah nilai tukar. Perubahan nilai tukar dapat mengubah harga relatif suatu menjadi lebih mahal atau lebih murah, sehingga nilai tukar terkadang digunakan sebagai alat untuk meningkatkan daya saing (mendorong ekspor). Perubahan posisi ekspor inilah yang kemudian berguna untuk memperbaiki posisi neraca perdagangan. Faktor lainnya yakni posisi Term of Trade Indonesia. Term of Trade yang membaik akan berdampak positif terhadap ekspor Indonesia.

\section{KAJIAN PUSTAKA DAN PERUMUSAN HIPOTESIS Perdagangan International}

Perdagangan internasional dapat diartikan sebagai sistem dimana negaranegara mengekspor dan mengimpor barang dan jasa pelayanan untuk mengembangkan spesialisasi dan spesialisasi meningkatkan produktivitas. Adapun perdagangan itu melibatkan satu negara atau negara yang berbeda sehingga perbedaan itu mempunyai konsekuensi ekonomis dan kesempatan untuk memperluas perdagangan dan suatu kesatuan untuk mengatur aliran barang dan sistem finansial harus menjamin kelancaran aliran barang dan jasa dalam perdagangan (Samuelson \& Nordhaus 1997). Ada beberapa teori yang berhubungan dengan perdagangan internasional, pertama, Teori Merkantilis. Para penganut merkantilisme berpendapat bahwa satu-satunya cara bagi suatu negara untuk menjadi kaya dan kuat adalah dengan melakukan sebanyak mungkin ekspor dan sedikit mungkin impor. Surplus ekspor yang dihasilkannya selanjutnya akan dibentuk dalam aliran emas lantakan, atau logam-logam mulia, khususnya emas dan perak (Salvatore \& Krugman 1997).

Kedua, Teori keunggulan mutlak oleh Adam Smith. Adam Smith menyatakan perdagangan antara dua negara didasarkan pada keunggulan absolut (absolute advantage). Jika sebuah negara lebih efisien dari pada negara lain dalam memproduksi sebuah komoditi, namun kurang efisien dibanding negara lain dalam memproduksi komoditi lainnya, maka kedua negara tersebut dapat memperoleh 
keuntungan dengan cara masing-masing melakukan spesialisasi dalam memproduksi komoditi yang memiliki hubungan absolut, dan menukarnya dengan komoditi lain yang memiliki kerugian absolut. Adam Smith percaya bahwa semua negara dapat memperoleh keuntungan dari perdagangan dan dengan tegas menyarankan untuk menjalankan kebijakan laissez-faire yaitu suatu kebijakan yang menyarankan sekecil mungkin intervensi pemerintah terhadap perekonomian. Terdapat pengecualian dalam kebijakan laissez-faire ini, yakni proteksi terhadap berbagai industri penting sebagai pertahanan negara (Salvatore \& Krugman 1997).

Ketiga, Teori keunggulan komparatif oleh John Stuart Mill dan David Ricardo. Teori ini menyatakan bahwa suatu negara akan menghasilkan dan kemudian mengekspor suatu barang yang memiliki comparative advantage terbesar dan mengimpor barang yang dimiliki comparative disadvantage (suatu barang yang dapat dihasilkan dengan lebih murah dan mengimpor barang yang kalau dihasilkan sendiri memakan ongkos yang besar). Nilai suatu barang ditentukan oleh banyaknya tenaga kerja yang dicurahkan untuk memproduksi barang tersebut. Kelebihan untuk teori comparative advantage ini adalah dapat menerangkan berapa nilai tukar dan berapa keuntungan karena pertukaran di mana kedua hal ini tidak dapat diterangkan oleh teori absolute advantage. David Ricardo (1772-1823) seorang tokoh aliran klasik menyatakan bahwa nilai penukaran ada jika barang tersebut memiliki nilai kegunaan. Dengan demikian sesuatu barang dapat ditukarkan bilamana barang tersebut dapat digunakan. Teori perdagangan internasional dikemukakan oleh David Ricardo mulai dengan anggapan bahwa lalu lintas pertukaran internasional hanya berlaku antara dua negara yang diantara mereka tidak ada tembok pabean, serta kedua negara tersebut hanya beredar uang emas (Tambunan 2001).

Keempat, Teori Heckscher-Ohlin. Heckscher-Ohlin dalam teori faktor proporsi menyatakan bahwa perbedaan dalam opportunity cost suatu negara dengan negara lain karena adanya perbedaan dalam jumlah faktor produksi yang dimilikinya. Suatu negara memiliki tenaga kerja lebih banyak daripada negara lain, sedang negara lain memiliki capital lebih banyak dari pada negara tersebut sehingga dapat menyebabkan terjadinya pertukaran (Nopirin 1991). Negara yang memiliki faktor produksi relatif banyak atau murah dalam memproduksinya akan melakukan spesialisasi produksi untuk kemudian mengekspor barangnya. Sebaliknya, masingmasing negara akan mengimpor barang tertentu jika negara tersebut memiliki faktor produksi yang relatif langka atau mahal dalam memproduksinya.

\section{Ekspor}

Ekspor adalah benda-benda (termasuk jasa) yang dijual kepada penduduk negara lain ditambah dengan jasa-jasa yang diselenggarakan kepada penduduk negara tersebut, berupa pengangkutan dengan kapal, permodalan dan hal-hal lain yang membantu ekspor tersebut (Todaro 1983; Todaro 2000). Sehubungan dengan ekspor suatu komoditas, secara teoritis volume ekspor dari suatu negara merupakan 
selisih antara penawaran dan permintaan domestik (excess demand) bagi negara konsumen (Kindleberger \& Lindert 1983).

Ditinjau dari sudut pengeluaran, ekspor merupakan salah satu faktor terpenting dari GNP (Gross National Product), sehingga dengan berubahnya nilai ekspor maka pendapatan masyarakat secara langsung juga akan mengalami perubahan. Dilain pihak, tingginya ekspor suatu negara akan menyebabkan perekonomian tersebut akan sangat sensitif terhadap keguncangan-keguncangan atau fluktuasi yang terjadi di pasaran internasional maupun di perekonomian dunia. Suatu negara dapat mengekspor barang produksinya ke negara lain apabila barang tersebut diperlukan negara lain dan mereka tidak dapat memproduksi barang tersebut atau produksinya tidak dapat memenuhi keperluan dalam negeri. Faktor yang lebih penting lagi adalah kemampuan dari negara tersebut untuk mengeluarkan barangbarang yang dapat bersaing dalam pasaran luar negeri. Maksudnya, mutu dan harga barang yang dapat diekspor tersebut haruslah paling sedikit sama baiknya dengan yang diperjualbelikan dalam pasaran luar negeri. Secara umum boleh dikatakan bahwa semakin banyak jenis barang yang mempunyai keistimewaan yang sedemikian yang dihasilkan oleh suatu negara, semakin banyak ekspor yang dapat dilakukan (Sukirno 1985;Sukirno 2002).

Berdasarkan teori tersebut, maka ekspor suatu komoditas ke pasaran international dipengaruhi oleh beberapa faktor yaitu faktor domestik, harga luar negeri dan faktor permintaan dan penawaran domestik antarnegara. Selain itu secara implisit ekspor juga dipengaruhi oleh faktor nilai tukar (exchange rate) mata uang suatu negara dengan negara lain. Sedangkan menurut Samuelson dan Nordhaus (1997) menyatakan bahwa faktor-faktor yang mempengaruhi volume dan nilai ekspor suatu negara tergantung pada pendapatan dan output luar negeri, nilai tukar uang (kurs) serta harga relatif antara barang dalam negeri dan luar negeri.

\section{Hubungan Produksi terhadap Ekspor}

Ayuningsih dan Setiawina (2014) dalam penelitiannya menemukan bahwa peningkatan produksi secara parsial berpengaruh signifikan positif terhadap volume ekspor. Saat produksi mengalami peningkatan maka ketersediaan barang dalam negeri meningkat, sehingga penawaran barang di dalam dan luar negeri juga meningkat. Hal inilah yang mengakibatkan apabila produksi meningkat, maka volume ekspor juga meningkat.

Menurut Basri (2002) dari pengertian kegiatan produksi, apabila produksi $C P O$ terus mengalami peningkatan dan terjadinya excces supply maka $C P O$ yang berlebih tersebut akan diekspor ke luar negeri. Mariati (2009) menemukan bahwa produksi nasional $C P O$ meningkatkan ekspor $C P O$ Indonesia. Selain itu, penelitian empiris yang lebih komprehensif dilakukan oleh Azizah (2015) tentang ekspor CPO ke negara Jerman, Italia, Belanda, Spanyol, Rusia dan Ukraina (Uni Eropa) juga menemukan bahwa produksi $C P O$ berpengaruh positif terhadap jumlah ekspor $C P O$ 
Indonesia. Berdasar pada argumentasi dan hasil riset terdahulu maka dirumuskan hipotesis pertama sebagai berikut.

H1: Produksi minyak kelapa sawit $(C P O)$ berpengaruh terhadap ekspor $C P O$.

\section{Hubungan Kurs terhadap Ekspor}

Menurut Boediono (2001), apabila nilai rupiah terdepresiasi terhadap mata uang asing maka akan berdampak pada nilai ekspor yang naik sedangkan nilai impornya akan turun (apabila penawaran ekspor dan permintaan impor cukup elastis). Hal ini dikarenakan di pasaran internasional produk domestik kita menjadi kompetitif. Dengan meningkatnya nilai ekspor bersih akan berdampak pada meningkatnya permintaan agregat riil sehingga berdampak pada meningkatnya investasi. Sebaliknya, jika nilai tukar rupiah mengalami apresiasi maka akan menyebabkan turunnya nilai ekspor, karena harga produk domestik menjadi relatif mahal. Pengaruh fluktuasi nilai tukar terhadap ekspor ini menarik perhatian beberapa pengamat ekonomi untuk menelitinya. Susilo (2001) misalnya menemukan bahwa fluktuasi nilai tukar memiliki dampak yang signifikan terhadap ekspor riil non migas pada jangka pendek. Lebih lanjut penelitian yang dilakukan oleh Huchet-Bourdon dan Korinek (2012) tentang pengaruh nilai tukar terhadap perdagangan antara negara Chilie dan New Zealand juga menghasilkan analisis yang sama, yaitu perubahan nilai tukar mempengaruhi neraca perdagangan pada perekonomian terbuka kecil (Huchet-Bourdon \& Korinek 2012). Hipotesis dua dirumuskan sebagai berikut

H2: Nilai tukar rupiah berpengaruh terhadap ekspor $C P O$.

\section{Hubungan Harga terhadap Ekspor}

Menurut Boediono (2001), tingginya harga mencerminkan kelangkaan dari barang tersebut. Ketika sampai tingkat harga tertinggi konsumen cenderung menggantikan barang tersebut dengan barang lain yang mempunyai hubungan dekat dan relatif lebih murah. Hukum penawaran menyatakan apabila semakin tinggi harga, jumlah barang yang ditawarkan semakin banyak. Sebaliknya semakin rendah harga barang, jumlah barang yang ditawarkan semakin sedikit.

Menurut Lipsey (1995) harga dan kuantitas/jumlah permintaan suatu komoditi berhubungan secara negatif. Artinya semakin tinggi harga suatu komoditi maka jumlah permintaan terhadap komoditi tersebut akan semakin berkurang, ceteris paribus. Untuk harga ekspor, Lipsey (1995) menyatakan bahwa suatu hipotesis ekonomi yang mendasar adalah bahwa untuk kebanyakan komoditi, harga yang ditawarkan berhubungan secara negatif dengan jumlah yang diminta, atau dengan kata lain semakin besar harga komoditi maka akan semakin sedikit kuantitas komoditi tersebut yang diminta. Sebaliknya harga berhubungan secara positif dengan penawaran. Semakin tinggi harga maka akan semakin banyak kuantitas yang 
ditawarkan. Dengan argumentasi dan hasil riset terdahulu, maka dirumuskan hipotesis tiga sebagai berikut.

H3: Harga $C P O$ berpengaruh terhadap Ekspor $C P O$.

\section{Hubungan Term of Trade terhadap Ekspor}

Term of Trade merupakan komponen dari harga ekspor dibagi dengan harga impor. Di dalam hal ini adalah harga barang-barang yang diperdagangkan di pasar dunia. Semakin tinggi Term of Trade suatu negara maka preferensi untuk melakukan ekspor semakin tinggi dan preferensi untuk melakukan impor juga semakin kecil. Hubungan Term of Trade dengan tingkat ekspor berlaku positif, semakin tinggi Term of Trade maka volume ekspor akan meningkat. Menurut Apridar (2009) bila Term of Trade (ToT) lebih besar dari 100 atau kenaikan Term of Trade (ToT) berarti terjadi perkembangan perdagangan luar negeri yang positif atau lebih baik karena dengan nilai ekspor tertentu diperoleh nilai impor yang lebih besar.

Selain itu penelitian yang dilakukan Mendoza (1995) terhadap negara industri, beberapa negara berkembang di Timur Tengah, Afrika dan beberapa negara Asia seperti Cina dan Indonesia menunjukkan bahwa Term of Trade juga berpengaruh positif dan tidak terlalu mengikuti business cycle (weekly procyclical). Dengan demikian, hipotesis empat dirumuskan sebagai berikut.

H4: ToT berpengaruh terhadap Ekspor CPO.

\section{Model Penelitian}

Model dalam penelitian ini dapat digambarkan sebagai berikut.

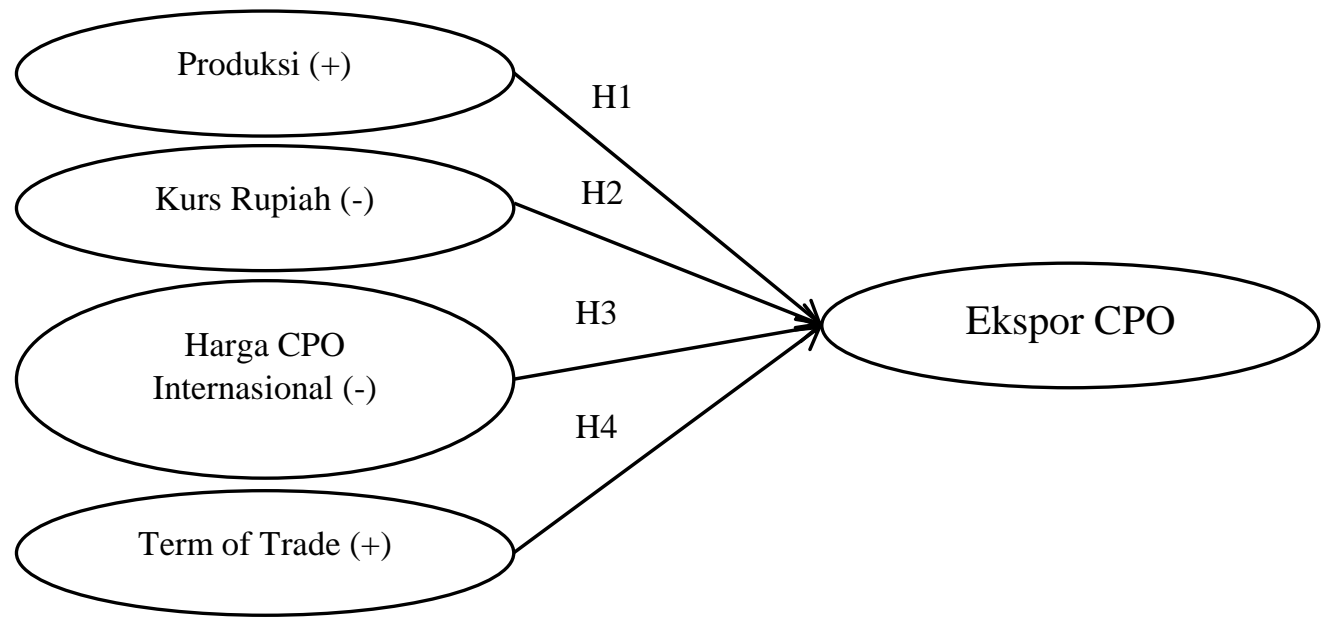

Gambar 1

Model Penelitian 


\section{METODA PENELITIAN}

\section{Jenis dan Sumber Data}

Data yang digunakan dalam penelitian ini adalah data sekunder bulanan (time series) yang diperoleh dari Badan Pusat Statistik (BPS), Bank Indonesia (BI) dan World Bank dari periode Oktober 2011 sampai periode Desember 2015. Data variabel dalam penelitian ini meliputi Ekspor $C P O$ (EXCPO), Produksi Kelapa Sawit (PROD), Harga CPO (PRICE), dan Term of Trade (ToT); semua data ini ditransformasi dalam bentuk logarithm natural (ln) untuk memberikan hasil yang valid dan konsisten.

\section{Metode Estimasi}

Penelitian ini menggunakan model Autoregressive Distributed Lag (ARDL) yang diperkenalkan oleh Pesaran et al. (2001). Pendekatan ini relatif baru terutama dalam membahas mengenai kointegrasi antar variabel untuk kepentingan analisis jangka panjang, jika dibandingkan dengan Engle-Granger Test, atau Maximum Likelihood Johansen Test. Perbedaan mendasar pendekatan ARDL dari pendekatan lain diantaranya karena fleksibilitasnya, meskipun variabel-variabel yang ada berbeda level integrasinya, baik $I(0), 1(1)$ ataupun sama levelnya, pendekatan ini bisa digunakan ( Pesaran \& Smith 1998; Pesaran \& Pesaran 1997; Pesaran et al., 2001). Sedangkan pendekatan lain, misalnya kointegrasi Johansen-Juselius mengharuskan semua variabel sama level integrasinya (Shrestha \& Chowdhury 2005). Selanjutnya, pendekatan ARDL merupakan model yang secara statitstik lebih signifikan untuk menentukan hubungan kointegrasi untuk data yang kecil, sedangkan model Johansen kointegrasi membutuhkan sampel yang banyak. Terakhir, dalam model ARDL setiap variabel bisa memiliki lag optimal yang berbeda-beda (Pahlavani et al., 2005).

Dalam mengatasi perbedaan level integrasi antar variabel sebagaimana dijelaskan, Pesaran et al. (2001) menggunakan bound testing procedure sebagai uji kointegrasi untuk estimasi dalam jangka panjang dengan F-test. Langkah selanjutnya adalah melakukan estimasi koefisien hubungan jangka panjang, diikuti estimasi jangka pendek dari semua variabel dengan format error correction dari model ARDL. Melalui ECM bisa ditentukan kecepatan penyesuaian ke arah keseimbangan (Pesaran \& Pesaran 1997). Mengikuti Pesaran dan Shin (1998a) model umum dari $\operatorname{ARDL}(p, q)$ bisa ditulis.

$\emptyset(L) y_{t}=a_{0}+a_{1} t+\beta^{\prime} x_{t}+\sum_{i=0}^{q-1} \beta_{j}^{* \prime} \Delta x_{t-j}-\emptyset^{*}(L) \Delta y_{t}+\mu_{t}$ 1

dimana $\emptyset(L)=1-\sum_{j=1}^{p} \emptyset_{j} L^{j}$, dan $\beta(L)=\sum_{j=0}^{q} \beta_{j} L^{j}, y_{t}$ adalah variabel dependen, $x_{t}$ adalah variabel independen dan $L$ adalah lag operator. Dalam penyesuaian dan koreksi kesalahan pada jangka pendek ke arah keseimbangan jangka panjang, maka model ARDL, mengikuti Pesaran et al. (2001) membutuhkan model ECM, 
$\Delta y_{t}=c_{0}+c_{1} t+\pi_{y y} y_{t-1}+\pi_{y x x} x_{t-1}+\sum_{i=1}^{p-1} \varphi_{i}^{\prime} \Delta z_{t-i}+w^{\prime \Delta x_{t}}+\mu_{t}$

Sedangkan untuk model dasar ekspor CPO pada penelitian ini sebagai berikut,

$\ln E X C P O_{t}=\alpha_{0}+\alpha_{1} \ln P R_{t}+\alpha_{2} \ln P C_{t}+\alpha_{3} \ln T o T_{t}+\alpha_{4} \ln E X C_{t}+\varepsilon_{t}$ 3

dimana $E X C P O$ adalah jumlah ekspor $C P O$ pada periode $t$ ditransformasikan dalam bentuk logarithm natural (ln); $P R$ adalah jumlah produksi kelapa sawit periode $t$ dalam bentul $\ln$; PC adalah harga CPO internasional periode $t$ dalam $l n$; ToT adalah term of trade pada periode $t$ dalam bentuk $l n$; dan EXC adalah nilai tukar rupiah terhadap US dollar pada periode $t$ ditransformasikan dalam bentuk $l n$.

Untuk analisis stabilitas ekspor CPO dalam jangka panjang, pendekatan ARDL bisa diterapkan dengan memasukkan persamaan (3) dalam format error correction sehingga terjadi proses penyesuaian jangka pendek ke jangka panjang. Model error correction-ARDL penelitian ini mengikuti Pesaran et al., (2001), bisa dituliskan.

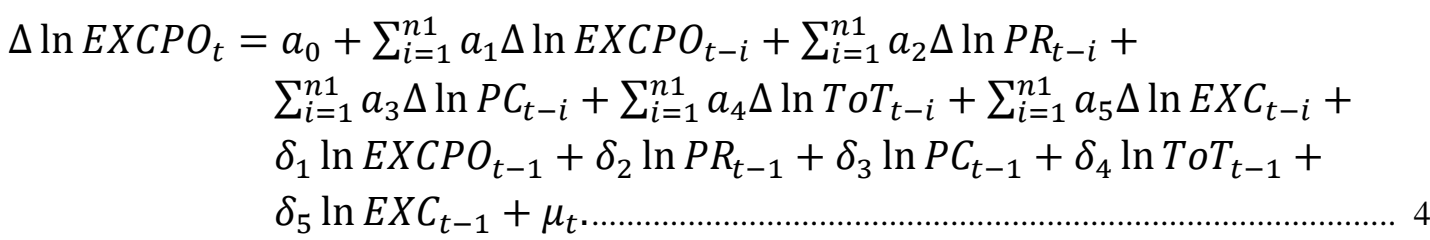

dimana parameter $\delta_{t}, i=1,2,3,4,5$ sebagai multiplier jangka panjang, sedangkan fungsi parameter $a_{1}, a_{2}, a_{3}, a_{4}, a_{5}$ sebagai koefisien jangka pendek dari model ARDL. Dalam model ARDL, perlu dilakukan F-statistik untuk menguji hipotesis awal (null hypothesis) yang menyatakan bahwa tidak ada kointegrasi bisa digambarkan ( $H_{0}: \delta_{1}=\delta_{2}=\delta_{3}=\delta_{4}=\delta_{5}=0$ ), sedang hipotesis alternatif (adanya kointegrasi antar variabel) yang bisa digambarkan $\left(H_{0}: \delta_{1} \neq \delta_{2} \neq \delta_{3} \neq\right.$ $\delta_{4} \neq \delta_{5} \neq 0$ ). Dalam tahap ini, F-statistik yang sudah diuji akan dibandingkan dengan nilai kritis (critical value) sebagaimana diajukan oleh Pesaran et al., (2001). Nilai kritis ini mempunyai batas bawah (lower band) dan batas atas (upper band) yang memungkinkan dilakukan klasifikasi vairabel menjadi $I(1), I(0)$, atau sama level integrasinya. Setelah terjadi kointegrasi, kemudian bisa dilakukan estimasi jangka panjang dan estimasi penyesuaian jangka pendek. Selain itu, untuk menguji stabilitas ekspor CPO digunakan CUSUM dan CUSUMQ test, diterapkan pada residual dalam model. CUSUM test berdasar pada cumulative sum of recursive residuals, jika plot CUSUM berada pada nilai kritis 5 persen (tidak keluar dari garis batas atas dan bawah), maka estimasi dianggap stabil, begitu sebaliknya. Hal yang sama juga berlaku untuk CUSUMQ test yang bedasar pada cumulative sum of squares of recursive residuals. 


\section{ANALISIS DAN PEMBAHASAN}

Sebagai langkah awal, model ARDL memang tidak mengharuskan adanya uji akar unit (unit root test) untuk mengetahui apakah variabel mempunyai integrasi pada level $I(0)$ atau $I(1)$, tetapi perlu dilakukan uji F-statistik atau bound test dengan batas atas nilai kritis pada level I(1) dan batas bawah di level $I(0)$. Dengan membandingkan F-statistik dengan nilai kritis, hipotesis nol (null hypothesis) yang menyatakan tidak ada kointegrasi ditolak apabila F-statistik lebih besar dari batas atas (upper bound) nilai kritis. Sedangkan jika F-statistik lebih kecil dari batas bawah (lower bound), maka hipotesis nol tidak bisa ditolak, artinya H0 diterima (tidak ada kointegrasi). Tetapi, apabila nilai itu berada diantara batas bawah dan atas maka hasilnya tidak meyakinkan. Pada penelitian ini, lag 4 merupakan lag maksimal yang digunakan. Berikut ini hasil dari bound test, pada tabel 2 (Lampiran 1).

Hasil bound test menunjukkan bahwa F-statistik pada model ekspor CPO dengan lag maksimal $4(6,88)$ lebih besar dari pada batas atas (upper bound) nilai kritis, baik pada taraf 1 persen $(5,72), 5$ persen $(4,57)$ atau 10 persen $(4,06)$. Artinya, $\mathrm{H} 0$ yang menyatakan tidak ada kointegrasi antar variabel bisa ditolak dan menerima hipotesis alternatif (H1) yaitu adanya kointegrasi untuk penyesuaian jangka panjang, sehingga error correction bisa diestimasi.

Setelah lolos melakukan bound testing, maka estimasi jangka panjang dan penyesuaian jangka pendek (melalui ecm) bisa dilakukan. Berdasarkan Akaike Information Criterion (AIC), model ARDL terpilih adalah $(1,4,3,0,0)$. Berikut hasil estimasi $\operatorname{ARDL}(1,4,3,0,0)$.

Sebelum menganalisis lebih jauh-baik jangka pendek maupun jangka panjang - satu indikator penting perlu dicermati yaitu error correction untuk mengetahui penyesuaian jangka pendek. Ecm bertanda negatif dan sangat signifikan (taraf 1 persen), artinya bahwa adanya kointegrasi antar-variabel bisa dikonfirmasi. Koefisien ecm (-0.345) menandakan bahwa kesalahan jangka pendek akan dikoreksi sebesar 0.34 persen selama satu periode (bulan) menuju keseimbangan. Berdasarkan pada hasil estimasi di atas, menunjukkan bahwa dalam jangka pendek dan jangka panjang dalam model (3), terdapat beberapa variabel yang mempengaruhi ekspor $C P O$ Indonesia:

Pertama, adalah variabel ekspor itu sendiri. Ekspor $C P O$ ternyata dipengaruhi oleh ekspor $C P O$ pada periode sebelumnya $\left(t_{-1}\right)$, karena data penelitian ini bulanan, maka $t_{-1}$ adalah ekspor pada bulan sebelumnya. Ini hanya terjadi dalam jangka pendek. Artinya, performa ekspor $C P O$ yang baik pada bulan sebelumnya akan mempengaruhi secara positif dan signifikan terhadap ekpor $C P O$ pada periode sekarang dengan nilai koefisien bernilai positif 0,654 dan signikan secara statistik pada level 1 persen, maka apabila ekspor pada $t_{-1}$ naik sebesar 1 persen, akan menaikkan ekspor periode ini sebesar 0,65 persen. 
Hal ini memang belum dijelaskan pada penelitian-penelitian sebelumnya, tetapi dengan menggunakan model ARDL bisa diketahui bahwa kinerja ekspor $C P O$ tidak hanya dipengaruhi faktor makroekonomi, tetapi juga oleh kinerja ekspor pada periode sebelumnya.

Kedua, pengaruh produksi kelapa sawit dalam mempengaruhi ekspor $C P O$. Variabel produksi kelapa sawit mempunyai pengaruh jangka pendek, baik periode $t$ maupun pada periode sebelumnya $\left(\mathrm{t}_{-1}\right)$. Nilai koefisien produksi bertanda negatif dalam jangka pendek periode $t$ sebesar $-3,741$ yang signifikan pada level 1 persen, menunjukan apabila terjadi peningkatan produksi sebesar 1 persen maka ekspor $C P O$ akan mengalami penurunan sebesar 3,7 persen dengan asumsi harga $C P O$ internasional, nilai tukar rupiah terhadap dolar AS dan term of trade tidak mengalami perubahan atau cateris paribus. Sedangkan pada periode sebelumnya $\left(\mathrm{t}_{-1}\right)$ terjadi sebaliknya, koefisien produksi bertanda positif sebesar 3,243 dan signifikan pada level 5 persen. Hal ini menunjukkan apabila terjadi kenaikan produksi kelapa sawit pada periode sebelumnya (bulan sebelumnya) sebesar 1 persen akan menaikkan ekspor $C P O$ sebesar 3,24 persen. Angka ini cukup elastis, artinya dalam jangka pendek bisa terjadi dua kemungkinan pengaruh dari produksi kelapa sawit; apabila produksi naik pada periode ini yang terjadi ekspor akan turun sebab ketika supply (penawaran) mengalami kenaikan belum tentu akan ada permintaan yang tinggi, karena jargon J.B Say "supply creates its own demand" tidak terbukti. Hal ini berbeda jika kenaikan produksi kelapa sawit terjadi pada periode sebelumnya, yang memungkinkan tejadinya waktu penyesuaian untuk memberikan dorongan kepada ekspor, sehingga produksi kelapa sawit periode lalu bisa meningkatkan ekspor $C P O$ pada saat ini, tapi produksi naik saat ini belum tentu akan menaikkan ekspor.

Koefisien produksi yang bernilai positif, maka mempunyai hubungan positif terhadap ekspor $C P O$ dalam jangka pendek. Hal ini menandakan bahwa uji tanda sesuai dengan hipotesis yang digunakan dalam penelitian ini menunjukan bahwa produksi dalam jangka pendek signifikan dalam mempengaruhi ekspor CPO Indonesia. Hal ini sesuai dengan teori yang dikemukakan oleh Smith mengenai Teori Keunggulan Absolut yang membuktikan bahwa semakin tinggi produksi maka akan mengakibatkan tingginya volume ekspor. Komalasari (2009) menjelaskan bahwa adanya pengaruh secara positif antara peningkatan produksi terhadap penawaran ekspor. Saat produksi mengalami peningkatan maka ketersediaan $C P O$ meningkat dan penawaran $C P O$ di dalam maupun luar negeri meningkat, sehingga menyebabkan ekspor $C P O$ Indonesia juga akan mengalami kenaikan.

Nilai koefisien Produksi dalam jangka panjang sebesar -2,293 yang signifikan pada level 5 persen, menunjukan apabila terjadi peningkatan produksi sebesar 1 persen maka ekspor $C P O$ akan mengalami peningkatan sebesar 2,3 persen dengan asumsi harga $C P O$ internasional, nilai tukar rupiah terhadap dolar AS dan Term of Trade tidak mengalami perubahan atau cateris paribus. Koefisien produksi bernilai negatif, maka produksi mempunyai hubungan negatif terhadap ekspor $C P O$ dalam 
jangka panjang. bahwa produksi dalam jangka panjang signifikan dalam mempengaruhi ekspor $C P O$ Indonesia.

Ketiga, pengaruh harga $C P O$ internasional terhadap ekspor $C P O$. Dalam jangka pendek pada periode $\mathrm{t}_{-1}$ nilai koefisien harga $\mathrm{CPO}$ bertanda negatif sebesar 0,1736 yang signifikan pada level 10 persen, hal ini menunjukan apabila terjadi peningkatan harga $C P O$ sebesar 1 persen maka ekspor $C P O$ akan mengalami penurunan sebesar 0,17 persen dengan asumsi nilai tukar rupiah terhadap dolar AS, Term of Trade dan produksi kelapa sawit tidak mengalami perubahan atau cateris paribus. Koefisien harga $\mathrm{CPO}$ bernilai negatif, maka harga $\mathrm{CPO}$ mempunyai hubungan negatif terhadap ekspor $C P O$ dalam jangka pendek. Hal ini menandakan bahwa uji tanda sesuai dengan hipotesis yang digunakan dalam penelitian ini. Hal ini sesuai dengan teori Lipsey (1995) yang menyatakan harga dan kuantitas/jumlah permintaan suatu komoditi berhubungan secara negatif. Artinya semakin tinggi harga suatu komoditi maka jumlah permintaan (barang ekspor) terhadap komoditi tersebut akan semakin berkurang. Hasil penelitian ini sejalan dengan penelitian yang dilakukan oleh Abidin (2008) mengenai analisis ekspor minyak kelapa sawit (CPO) Indonesia. Dari hasil uji empiris ditemukan bahwa terdapatnya hubungan yang negatif dan signifikan antara harga $C P O$ nasional dan ekspor minyak kelapa sawit $(C P O)$ Indonesia.

Berdasarkan data Gabungan Perusahaan Kelapa Sawit Indonesia (GAPKI), Indonesia telah mencatatkan ekspor $C P O$ dan turunannya pada tahun 2014 mencapai 21,76 juta ton, sedikit meningkat dibandingkan tahun sebelumnya sebesar 21,22 juta ton. Namun demikian, peningkatan tersebut tidak disertai dengan peningkatan kebutuhan $C P O$ dunia, sehingga terjadi kelebihan pasokan $C P O$ di pasar international yang membuat harga terpengaruh secara negatif.

Nilai koefisien harga CPO dalam jangka panjang sebesar -1,1983 yang signifikan pada level 1 persen, menunjukan bahwa harga $C P O$ dalam jangka panjang signifikan dalam mempengaruhi ekspor $C P O$ Indonesia. Artinya, apabila terjadi kenaikan harga CPO internasional 1 persen akan menurunkan ekspor $C P O$ Indonesia sebesar 1,2 persen. Angka ini menunjukkan elastisitas yang cukup tinggi pengaruh harga internasional dalam jangka panjang. Tidak heran jika pengaruh negatif harga internasional ini juga ditemui di beberapa komoditas ekspor non migas lain. Misalnya, penelitian yang dilakukan oleh Sugiarsana dan Indrajaya (2012) menganalisis tentang pengaruh jumlah produksi, harga dan investasi terhadap volume ekspor tembaga Indonesia tahun 1995 sampai 2010. Dari hasil uji empiris ditemukan bahwa terdapatnya hubungan yang negatif antara harga tembaga dan volume ekspor tembaga Indonesia. Selanjutnya, penelitian yang dilakukan oleh Anggraini (2006) yang menunjukkan bahwa harga kopi dunia berpengaruh negatif dan signifikan terhadap permintaan ekspor kopi Indonesia dari Amerika Serikat. 
Selanjutnya menurut penelitian Siburian (2012) tentang Analisis FaktorFaktor Yang Mempengaruhi Ekspor Karet Alam Indonesia ke Singapura, menyatakan bahwa variabel Harga karet alam Indonesia dalam jangka pendek maupun dalam jangka panjang memiliki hubungan yang negatif terhadap ekspor karet alam Indonesia ke Singapura. Hal ini mengindikasikan bahwa variabel harga menjadi pertimbangan bagi negara pengimpor dalam menentukan volume karet yang akan diimpor dari Indonesia. Jika harga karet Indonesia tinggi, maka volume karet yang diperdagangkan ke negara tersebut akan semakin kecil dan sebaliknya.

Keempat, pengaruh Term of Trade terhadap ekspor CPO. Nilai koefisient Term of Trade dalam jangka pendek sebesar 0,751 yang signifikan pada level 5 persen, menunjukan dalam jangka pendek Term of Trade berpengaruh positif dan signifikan dalam mempengaruhi ekspor $C P O$ Indonesia. Menunjukkan pula apabila terjadi peningkatan Term of Trade sebesar 1 persen maka ekspor CPO akan mengalami kenaikan sebesar 0,75 persen dengan asumsi nilai tukar rupiah terhadap dolar AS, harga CPO internasional dan produksi kelapa sawit tidak mengalami perubahan atau cateris paribus. Sedangkan dalam jangka panjang, koefisien Term of Trade bertanda positif sebesar 2.1724 yang signifikan pada level 1 persen; menunjukkan bahwa Term of Trade dalam jangka panjang berpengaruh positif dan signifikan dalam mempengaruhi ekspor $C P O$ Indonesia. Menunjukkan pula apabila terjadi peningkatan Term of Trade sebesar 1 persen maka ekspor CPO akan mengalami kenaikan sebesar 2,17 persen dengan asumsi nilai tukar rupiah terhadap dolar AS, harga CPO internasional dan produksi kelapa sawit tidak mengalami perubahan atau cateris paribus. Artinya, ToT dalam jangka panjang mempunyai pengaruh yang besar dalam meningkatkan performa ekspor CPO Indonesia, mengingat nilai elastisitasnya cukup tinggi.

Konsep ToT yang paling umum digunakan, yaitu Net Barter Terms of Trade atau juga dapat disebut Commodity Terms of Trade. Net Barter Terms of Trade adalah perbandingan antara indeks harga ekspor dengan indeks harga impor. Kenaikan ekspor menunjukkan perbaikan di dalam nilai tukar perdagangan, artinya untuk sejumlah tertentu ekspor dapat diperoleh jumlah impor yang lebih banyak dengan melalui hubungan harga (Nopirin 1991). Hasil temuan dalam penelitian ini juga sesuai dengan teori bahwa Term of Trade yang membaik akan berdampak positif terhadap ekspor dan berdampak negatif terhadap impor. Hasil penelitian ini sesuai dengan penelitian Sugeng et al., (2010) dari Biro Riset Ekonomi - DKM Bank Indonesia.

Kelima, pengaruh kurs rupiah terhadap ekspor $C P O$. Dalam jangka pendek, nilai koefisien nilai tukar rupiah bertanda negatif sebesar -0,4809 dan signifikan pada level 1 persen; menunjukan nilai tukar berpengaruh negatif dan signifikan dalam terhadap ekspor $C P O$ Indonesia. Hasil riset menunjukkan pula apabila terjadi apresiasi (menguat) nilai tukar rupiah terhadap dolar AS sebesar 1 persen maka ekspor $\mathrm{CPO}$ akan menurun sebesar 0,48 persen dengan asumsi harga $C P O$ 
internasional dan produksi kelapa sawit dan ToT tidak mengalami perubahan atau cateris paribus. Sedangkan dalam jangka panjang, koefisien nilai tukar juga bertanda negatif sebesar -1,3902 yang signifikan pada level 1 persen; menunjukan bahwa nilai tukar dalam jangka panjang berpengaruh negatif dan signifikan dalam mempengaruhi Ekspor $C P O$ Indonesia. Menunjukan pula apabila terjadi penguatan nilai tukar (apresiasi) rupiah terhadap dolar AS sebesar 1 persen maka ekspor $C P O$ akan mengalami penurunan sebesar 1,39 persen dengan asumsi harga $C P O$ internasional dan produksi kelapa sawit tidak mengalami perubahan atau cateris paribus. Nilai koefisien jangka panjang $(-1,39)$ menunjukkan bawah nilai tukar rupiah mempunyai pengaruh yang besar untuk menurunkan ekspor $C P O$ Indonesia, mengingat nilai elastisitasnya cukup tinggi.

Hasil penelitian ini memperkuat teori mengenai kurs suatu negara dan hubungannya dengan ekspor impor. Boediono (2001) menjelaskan apabila nilai rupiah terapresiasi terhadap mata uang asing maka akan berdampak pada turunnya nilai ekspor sedangkan nilai impornya akan meningkat (apabila penawaran ekspor dan permintaan impor cukup elastis). Hal ini dikarenakan di pasaran internasional produk domestik menjadi lebih mahal. Dalam konteks penelitian ini, maka ketika mata uang rupiah mengalami apresiasi (menguat) terhadap dolar AS maka hal ini akan menyebabkan harga $C P O$ Indonesia di pasar internasional atau di negara tujuan menjadi relatif lebih mahal, sehingga menyebabkan terjadinya penurunan ekspor CPO. Hal ini sesuai dengan penelitian yang dilakukan oleh Wulantoro (2009), Alatas (2015) dan Azizah (2015).

Untuk menguji stabilitas jangka panjang bersama dengan penyesuaian jangka pendek, sebagaimana dijelaskan pada bagian metode penelitian, maka digunakan CUSUM dan CUSUMQ. CUSUM test berdasar pada cumulative sum of recursive residuals, jika plot CUSUM berada pada nilai kritis 5 persen (tidak keluar dari garis batas atas dan bawah), maka estimasi dianggap stabil, begitu sebaliknya. Hal yang sama juga berlaku untuk CUSUMQ test yang bedasar pada cumulative sum of squares of recursive residuals. Gambar (2) dibawah ini menunjukkan bahwa plot CUSUM dan CUSUMQ berada dalam garis batas, secara umum menunjukkan koefisien regresi stabil selama periode penelitian (Lihat lampiran 2).

\section{SIMPULAN, KETERBATASAN DAN SARAN}

\section{Simpulan}

Hasil analisis pengaruh harga $C P O$ internasional terhadap tingkat ekspor $C P O$ Indonesia dalam jangka pendek berpengaruh negatif dan signifikan. Begitu juga dalam jangka panjang, harga $C P O$ berpengaruh negatif dan signifikan dalam mempengaruhi ekspor $C P O$ Indonesia. Hal ini sesuai dengan teori permintaan yang menyatakan bahwa semakin tinggi harga suatu komoditi maka jumlah permintaan terhadap komoditi tersebut akan semakin berkurang. Hal serupa juga terjadi pada 
variabel nilai tukar rupiah terhadap ekspor $C P O$ dalam jangka pendek dan jangka panjang yang berkoefisien negatif dan signifikan dalam mempengaruhi ekspor $C P O$ Indonesia. Artinya jika rupiah menguat, ekspor $C P O$ akan turun baik dalam jangka pendek maupun jangka panjang.

Pengaruh variabel Term of Trade terhadap ekspor $C P O$ dalam jangka pendek dan jangka panjang berpengaruh positif signifikan dalam mempengaruhi ekspor $C P O$ Indonesia. Sedangkan pengaruh variabel produksi terhadap ekspor $C P O$ dalam jangka pendek memiliki nilai positif dan signifikan dalam mempengaruhi ekspor CPO Indonesia. Begitu juga dalam jangka panjang, produksi memiliki pengaruh yang positif dan signifikan. Tetapi dalam jangka panjang, produksi kelapa sawit tidak menaikkan ekspor CPO. Melalui analisis CUSUM dan CUSUMQ bisa disimpulkan bahwa model ekspor $C P O$ Indonesia dalam keadaan stabil selama periode penelitian.

\section{Keterbatasan dan Saran}

Penelitian ini terbatas pada variabel-variabel yang mempengaruhi ekspor $C P O$ hanya dari negera pengekspor, atau dari faktor internal Indonesia. Sehingga masih belum mampu menangkap secara komprehensif, karena tidak bisa dipungkiri bahwa kondisi ekonomi negara-negara pengimpor $C P O$ juga mempunyai pengaruh dalam permintaan ekspor. Penelitian ini akan lebih menyeluruh, apabila dimasukkan variabel-variabel kondisi ekonomi negara impotir terbesar $C P O$, seperti $G D P$ atau pertumbuhan ekonominya dan permintaan $C P O$ negara importir. Negara pengimpor terbesar $C P O$ Indonesia adalah India, disusul Tingkok pada urutan kedua. Saran untuk penelitian berikutnya: perlu ditambahkan varibel kondisi ekonomi negara importir (GDP India, Tiongkok) serta permintaan dalam negeri akan $C P O$ India dan Tiongkok, supaya hasil lebih komprehensif.

\section{Implikasi}

Dari berbagai kesimpulan yang telah dirangkumkan di atas, sebagai implikasi kebijakan bagi Pemerintah dalam upaya peningkatan nilai ekspor sebagai berikut:

1. Indonesia merupakan produsen $C P O$ terbesar di dunia. Dengan peran yang cukup besar Indonesia diharapkan harus dapat meningkatkan kualitas minyak kelapa sawit $(C P O)$ yang sesuai dengan standar yang telah ditetapkan oleh negara-negara importir di pasar internasional. Maka dari itu, perlu adanya sinergitas kebijakan pemerintah yang mendukung daya saing hilirisasi industri sawit untuk menguasai pasar internasional.

2. Sebagai negara pengekspor dan produsen $C P O$ terbesar dunia, Indonesia perlu mengupayakan untuk menjadi penentu harga atau prive maker $C P O$ dunia.

3. Fluktuasi harga minyak sawit dunia hendaknya mampu diatasi pemerintah dengan meningkatkan stok minyak sawit dalam negeri agar gejolak kenaikan harga dunia tidak terlalu berimbas ke nilai ekspor kelapa sawit Indonesia.

4. Menjaga nilai Term of Trade agar tetap tinggi nilainya, hal itu akan meningkatkan aliran modal masuk yang berasal dari perdagangan yang selanjutnya dapat 
mengapresiasi nilai tukar riil dan sebaliknya. Term of Trade yang membaik akan berdampak positif terhadap ekspor.

5. Dengan rezim nilai tukar mengambang bebas (free floating exchange rate) yang telah diadopsi Indonesia, pemerintah perlu menerapkan peringatan dini gejolak nilai tukar rupiah, sebab jika variabel kurs mengalami apresiasi, akibatnya cukup besar dalam menurunkan ekspor minyak kelapa sawit Indonesia.

\section{DAFTAR PUSTAKA}

(BPS), Badan Pusat Statistik. n.d. “Jawa Tengah Dalam Angka 2008-2012.” BPS Propinsi Jawa Tengah. Semarang.

(Dirjen), Direktorat Jendral Perkebunan. 2016. Statistik perkebunan Indonesia 20142016: kelapa sawit (oil palm). Jakarta: Sekretariat Direktorat Jenderal Perkebunan.

https://doi.org/http://ditjenbun.pertanian.go.id/tinymcpuk/gambar/file/statistik /2016/SAWIT 2014-2016.pdf.

Abidin, Z. 2008. "Analisis ekspor minyak kelapa sawit (CPO) Indonesia." Jurnal Aplikasi Manajemen 6 (1): 139-44.

Agustian, A. 2002. "Analisis dinamika ekspor dan keunggulan komparatif minyak kelapa sawit (CPO) di Indonesia." SOCA (Socio-Economic Of Agriculturre And Agribusiness) 4 (3): 1-24.

Alatas, Andi. 2015. "Trend Produksi dan ekspor minyak sawit (CPO) Indonesia." Journal of Agribusiness and Rural Development Research 1 (2): 114-24. https://doi.org/10.18196/agr.1215.

Anggraini, Dewi. 2006. "Faktor-Faktor yang mempengaruhi permintaan ekspor kopi Indonesia dari Amerika Serikat." Program Pascasarjana Universitas Diponegoro Semarang.

Apridar. 2009. Ekonomi internasional, sejarah, teori, konsep dan permasalahan dalam aplikasinya. Cetakan pertama. Yogyakarta: Graha Ilmu.

Ayuningsih, N. S. M, dan N. D Setiawina. 2014. "Pengaruh jumlah produksi, kurs dollar Amerika Serikat dan luas areal lahan terhadap ekspor karet Indonesia tahun 1993-2013.” E-Jurnal Ekonomi Pembangunan Unud 3 (8): 366-75.

Azizah, Nur. 2015. "Analisis ekspor crude palm oil (CPO) Indonesia di Uni Eropa." Economics Development Analysis Journal 4 (3): 330-37.

Basri, Faisal H. 2002. Perekonomian Indonesia: tantangan dan harapan bagi kebangkitan ekonomi Indonesia. Jakarta: Erlangga.

Boediono. 2001. Teori dan aplikasi statistika dan probabilitas. Bandung: PT. Remaja Rosda Karya. 
Huchet-Bourdon, Marilyne, dan Jane Korinek. 2012. "Trade effects of exchange rates and their volatility: Chile and New Zealand. OECD trade policy papers." OECD Publishing Paris.

Huda, Syamsul. 2006. "Analisis beberapa faktor yang mempengaruhi ekspor non migas Indonesia ke Jepang.” Jurnal iIlmu-Ilmu Ekonomi 6 (2): 117-24.

Kindleberger, Charles P, dan Peter H Lindert. 1983. Ekonomi internasional. Jakarta: Erlangga.

Lipsey, Richard G. 1995. Pengantar makroekonomi. Edisi Kese. Jakarta: Binarupa Aksara.

Mariati, R. 2009. "Pengaruh produksi nasional, konsumsi dunia dan harga dunia terhadap ekspor crude palm oil (CPO) di Indonesia." Jurnal Ekonomi Pertanian dan Pembangunan 6 (1): 30-35.

Mendoza, Enrique. 1995. "The terms of trade, the real exchange rate, and economic fluctuations." International Economic Review 36 (1): 101-37. https://doi.org/10.2307/2527429.

Munadi, Ernawati. 2007. "Penurunan pajak ekspor dan dampaknya terhadap ekspor minyak kelapa sawit Indonesia ke India (pendekatan error correction ,odel).” Jurnal Informatika Pertanian 16 (2): 1020-36.

Nopirin. 1991. Ekonomi internasional. Edisi kedu. Yogyakarta: BPFE-UGM.

Pahlavani, Mosayeb, Ed Wilson, dan Andrew C. Worthingt. 2005. "Trade-GDP nexus in Iran: an application of the autoregressive distributed lag (ARDL) model." American Journal of Applied Sciences 2 (7): 1158-65. https://doi.org/10.3844/ajassp.2005.1158.1165.

Pesaran, M. H., Shin, Y. 1999. "An autoregressive distributed lag modelling approach to cointegration analysis. Dalam S. Strom, ed." In Econometrics and Economic Theory in the 20th Century: The Ragnar Frisch Centennial Symposium., 33. Cambridge: Cambridge University Press. https://doi.org/10.1017/CCOL521633230.

Pesaran, M. Hashem, dan Bahram Pesaran. 1997. Working with microfit 4.0: interactive econometric analysis. Oxford: Oxford University Press.

Pesaran, M. Hashem, Yongcheol Shin, dan Richard J. Smith. 2001. "Bounds testing approaches to the analysis of level relationships." Journal of Applied Econometrics 16 (3): 289-326. https://doi.org/10.1002/jae.616.

Pesaran, M Hashem, dan Ron P Smith. 1998. "Structural analysis of cointegrating VARs." Journal of Economic Surveys 12 (5): 471-505. https://doi.org/10.1111/1467-6419.00065.

Salvatore, Dominick, dan Paul R Krugman. 1997. Ekonomi internasional. Jakarta: 


\section{Penerbit Erlangga.}

Samuelson, Paul A, dan William D Nordhaus. 1997. Mikroekonomi. Jakarta: Penerbit Erlangga.

Shrestha, Min B., dan Khorshed Chowdhury. 2005. "ARDL modelling approach to testing the financial liberalisation hypothesis."

Siburian, Onike. 2012. "Analisis faktor-faktor yang mempengaruhi ekspor karet alam Indonesia ke Singapura tahun 1980-2010.” Economics Development Analysis Journal 1 (2).

Sugeng, M. N. Nugroho, Ibrahim, dan Yanifitri. 2010. "Pengaruh dinamika penawaran dan permintaan valas terhadap nilai tukar rupiah dan kinerja perekonomian Indonesia." Buletin Ekonomi Moneter dan Perbankan (Januari), 311-53.

Sugiarsana, M, dan I. G. B. Indrajaya. 2012. "Analisis pengaruh jumlah produksi, harga dan investasi terhadap volume ekspor tembaga Indonesia tahun 19952010." Jurnal Ekonomi Pembangunan Universitas Udayana 2 (1): 10-19.

Sukirno, Sadono. 1985. Ekonomi Pembangunan - Proses, Masalah dan Dasar Kebijakan. Jakarta: LP3ES-UI dengan Bina Grafika.

—. 2002. Pengantar teori makroekonomi. Edisi Kedu. Jakarta: PT. Raja Grafinda Persada.

Susilo, A. 2001. "Dampak ketidakpastian nilai tukar Indonesia terhadap pertumbuhan ekspor periode 1979-1988: suatu pendekatan kointegrasi dan model koreksi kesalahan.” Universitas Indonesia Jakarta.

Tambunan, Tulus. 2001. Perekonomian Indonesia: teori dan temuan empiris. Jakarta: Ghalia Indonesia.

Todaro, Michael P. 1983. Ekonomi pembangunan di dunia ketiga. Jakarta: Penerbit Balai Aksara.

- 2000. Economic development. Seventh ed. New York: New York University, Addison Mesley.

Wulantoro, Aris. 2009. "Kebijakan dan pertumbuhan ekspor minyak kelapa sawit Indonesia ke negara Belanda tahun 1985-2007." Pascasarjana Universitas Andalas. 


\section{LAMPIRAN 1}

Tabel 1

Kontribusi Sektor Non Migas terhadap Cadangan Devisa Indonesia tahun 2013-2015 (dalam juta Rupiah)

\begin{tabular}{lcccc}
\hline \multicolumn{1}{c}{$\begin{array}{c}\text { Kelompok Hasil } \\
\text { Industri }\end{array}$} & $\mathbf{2 0 1 3}$ & $\mathbf{2 0 1 4}$ & $\mathbf{2 0 1 5}$ & $\begin{array}{c}\text { Pertumbuhan } \\
(\%)\end{array}$ \\
\hline $\begin{array}{l}\text { Minyak Kelapa } \\
\text { Sawit }\end{array}$ & 20.660 & 23.711 & 20.746 & 19.45 \\
$\begin{array}{l}\text { Biji Baja, Mesin } \\
\text { dan Otomotif }\end{array}$ & 14.684 & 5.813 & 14.455 & 13.55 \\
$\begin{array}{l}\text { Tekstil } \\
\text { Elektronika }\end{array}$ & 12.661 & 12.720 & 12.262 & 11.50 \\
$\begin{array}{l}\text { Pengolahan Karet } \\
\text { Makanan dan }\end{array}$ & 8.520 & 8.066 & 6.913 & 6.40 \\
$\begin{array}{l}\text { Minuman } \\
\text { Pulp dan Kertas }\end{array}$ & 5.724 & 7.497 & 6.171 & 5.79 \\
$\begin{array}{l}\text { Peng. Kayu } \\
\text { Emas, perak, logam }\end{array}$ & 5.379 & 5.554 & 5.597 & 5.25 \\
mulia, dll & 4.727 & 5.498 & 5.332 & 5.00 \\
Kulit, Barang Kulit & 4.727 & 5.202 & 5.188 & 4.86 \\
\hline
\end{tabular}

Sumber : Badan Pusat Statistik, 2013-2015

Tabel 2

ARDL Bound Test

\begin{tabular}{|c|c|c|c|}
\hline \multicolumn{2}{|c|}{ Model Ekspor CPO } & $\boldsymbol{k}$ & F-Statistik \\
\hline \multirow{2}{*}{\multicolumn{2}{|c|}{$\begin{array}{l}\text { EXCPO } \\
=f(\text { Produksi,Harga CPO int,ToT,Kurs })\end{array}$}} & \multirow[b]{2}{*}{4} & $\operatorname{Lag}(4,4,4,4)$ \\
\hline & & & $6.879575^{*}$ \\
\hline \multirow{2}{*}{ Nilai Kritis } & \multicolumn{3}{|c|}{ Tabel CI(v): Case V* } \\
\hline & Lower Bound $I(0)$ & & Upper Bound $I(1)$ \\
\hline $1 \%$ & 4.4 & & 5.72 \\
\hline $5 \%$ & 3.47 & & 4.57 \\
\hline $10 \%$ & 3.03 & & 4.06 \\
\hline
\end{tabular}

Keterangan: Nilai kritis (critical value) dalam tes ini berdasarkan pada al.,kasus V: Unrestricted intercept and unrestricted trend (Pesaran et al., 2001, h. 301). 
Tabel 3

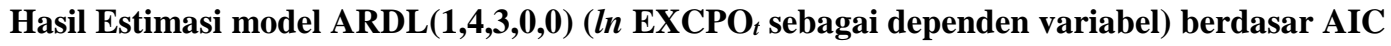

A. Koefisien Jangka Pendek

\begin{tabular}{|c|c|c|c|}
\hline Regressor & Koefisien & Std. Error & T-ratio[Prob] \\
\hline Intercept & 19.125 & 5.9821 & $3.1971[0.00]$ \\
\hline$\Delta \ln E X C P O_{t-1}$ & 0.6540 & 0.0932 & $7.0163[0.00]$ \\
\hline$\Delta \ln P R_{t}$ & -3.7417 & 1.1637 & $-3.2153[0.00]$ \\
\hline$\Delta \ln P R_{t-1}$ & 3.2434 & 1.5390 & $2.1074[0.04]$ \\
\hline$\Delta \ln P R_{t-2}$ & 0.9498 & 1.5206 & $0.6246[0.53]$ \\
\hline$\Delta \ln P R_{t-3}$ & 0.5658 & 1.5086 & $0.3750[0.70]$ \\
\hline$\Delta \ln P R_{t-4}$ & -1.8109 & 1.0305 & $-1.7573[0.08]$ \\
\hline$\Delta \ln P C_{t}$ & -0.0672 & 0.0670 & $-1.0030[0.32]$ \\
\hline$\Delta \ln P C_{t-1}$ & -0.1736 & 0.0916 & $-1.8941[0.06]$ \\
\hline$\Delta \ln P C_{t-2}$ & -0.0604 & 0.0924 & $-0.6545[0.51]$ \\
\hline$\Delta \ln P C_{t-3}$ & -0.1132 & 0.0776 & $-1.4577[0.15]$ \\
\hline$\Delta \operatorname{lnToT_{t}}$ & 0.7515 & 0.3187 & $2.3577[0.02]$ \\
\hline$\Delta \ln E X C_{t}$ & -0.4809 & 0.1435 & $-3.3510[0.00]$ \\
\hline Trend & 0.0076 & 0.0037 & $2.0607[0.04]$ \\
\hline$e c_{t-1}$ & -0.3459 & 0.0932 & $-3.7115[0.00]$ \\
\hline \multicolumn{4}{|c|}{$R^{2}=0.975$, Adjusted $R^{2}=0.967$, F-stat $=113.26[0.00]$, DW-stat $=2.132$} \\
\hline BG-LM test $=$ & Glejse & $8.927[0.12$ & \\
\hline
\end{tabular}

B. Koefisien Jangka Panjang

\begin{tabular}{lccc}
\hline & Koefisien & Std. Error & T-ratio[Prob] \\
\hline Intercept & 55.280 & 15.431 & $3.5822[0.00]$ \\
$\ln P R$ & -2.2937 & 1.0611 & $-2.1614[0.03]$ \\
$\ln P C$ & -1.1983 & 0.1605 & $-7.4660[0.00]$ \\
$\ln$ ToT & 2.1724 & 0.6147 & $3.5336[0.00]$ \\
$\ln$ EXC & -1.3902 & 0.4737 & $-2.9346[0.00]$ \\
Trend & 0.0221 & 0.0102 & $2.1498[0.03]$ \\
\hline
\end{tabular}

Keterangan: BG-LM (Breusch-Godfrey Lagrange Multiplier) merupakan test residual mendeteksi serial korelasi. Glejser test untuk menguji adanya heteroskedastisitas; dengan $p$-value yang tertera dalam [..]. 


\section{LAMPIRAN 2}
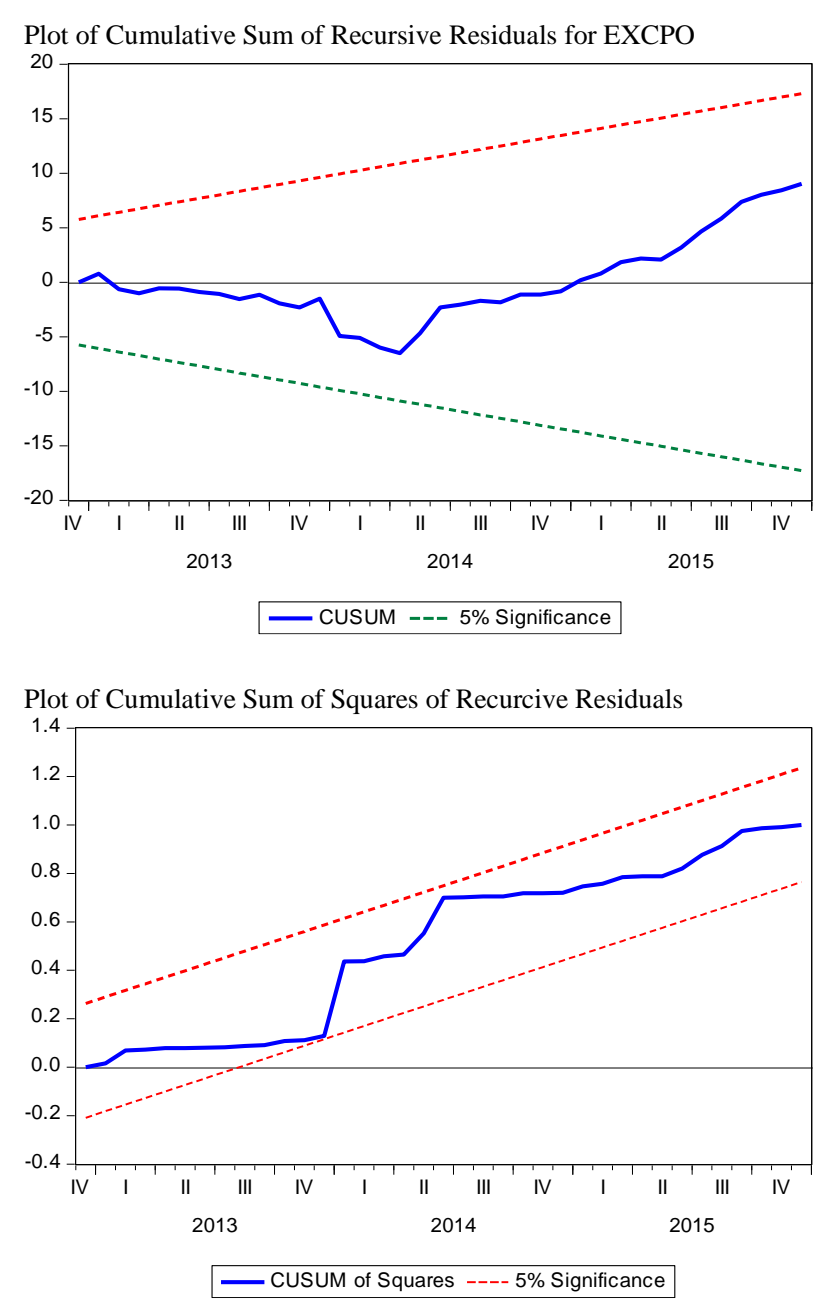

Plot CUSUM (kiri) dan CUSUMQ (kanan) untuk menguji stabilitas 
